ISSN 0258-7122

Bangladesh J. Agril. Res. 34(4) : 537-543, December 2009

\title{
MICROBIAL RESPIRATION AND NITROGEN MINERALIZATION IN SOIL AMENDED WITH DIFFERENT PROPORTIONS OF VERMICOMPOST AND COIR DUST
}

\author{
B. C. WALPOLA AND S. D. WANNIARACHCHI
}

\begin{abstract}
The effect of different combinations of vermicompost and coir dust on microbial respiration and nitrogen mineralization in soil was studied under laboratory conditions. Treatment with $75 \%$ vermicompost and $25 \%$ coir dust $\left(\mathrm{T}_{2}\right)$ demonstrated the highest carbon mineralization and $\mathrm{NH}_{4}^{+}-\mathrm{N}$ contents followed by treatment $\mathrm{T}_{1}\left(100 \%\right.$ vermicompost) and $\mathrm{T}_{3}$ (50\% vermicompost and $50 \%$ coir dust). Despite the varied $\mathrm{NO}_{3}-\mathrm{N}$ contents at the initial stages of incubation, the $\mathrm{NO}_{3}-\mathrm{N}$ content steadily increased for all the treatments at day 49 onwards. The highest $\mathrm{NO}_{3}-\mathrm{N}$ content was observed in $\mathrm{T}_{1}$ followed by that in $\mathrm{T}_{2}$ and $\mathrm{T}_{3}$. Such studies need be conducted under field conditions to reach a definite conclusion.
\end{abstract}

Key Words: Vermicompost, coir dust, mineralization.

\section{Introduction}

Vermicomposting means the use of earthworms for composting organic residues. Earthworms can eat as much as their own body weight per day. It is estimated that 1000 tons of moist organic manure can be converted into 300 tons of compost by earthworms (Sajnanath and Sushama, 2004).

Vermicompost could release nutrients slowly and steadily into the system and enables the plants to absorb these nutrients over time (Sharma, 2003). It does not have any adverse effect on soil, plant and environment and it improves soil aeration and texture thereby reducing soil compaction. However, $100 \%$ vermicompost would have poor porosity and aeration and high soluble salt concentrations (Atiyeh et al., 2000).

Coir (coconut fibre) dust is a major by-product of coir fibre industry. It has superior structural quality, water absorption ability, CEC and dry density compared to either sphagnum or sedge peat (Cresswell, 2006). Coir dust is an excellent surface mulch in all kinds of soils. It absorbs more than eight times its weight of water. It is reported that by incorporation of $2 \%$ coir dust (by weight) into sandy soil, the water holding capacity of the soil is increased by $40 \%$ (Thampan, 1981). It is about $70 \%$ of the weight of the coconut husk.

Despite vermicompost is a nutrient-rich natural fertilizer, its poor physical properties are a matter of concern. Coir dust, on the other hand, possesses good

Department of Soil Science, Faculty of Agriculture, University of Ruhuna, Mapalana, Kamburupitiya, Sri Lanka. 
physical qualities, though it has low nutrient content. However, the soil organic matter can be maintained by application of coir dust which has a very high $\mathrm{C}$ : $\mathrm{N}$ ratio, either in mixture with the organic manure like vermicompost or coir dust alone. Therefore, the present study was undertaken to assess the effect of different combinations of vermicompost and coir dust on microbial respiration and nitrogen mineralization.

\section{Materials and Method}

\section{Soil collection}

The experiment was conducted in the laboratory of the Faculty of Agriculture, University of Ruhuna, Mapalana, Kamburupitiya, Sri Lanka. The soil used in this study belongs to Red Yellow Podzolic great soil group and is classified as Hapludults according to the USDA soil taxonomy (Mapa et al., 1999). Soil samples were collected randomly from several locations of the research farm of the Faculty of Agriculture, University of Ruhuna, Sri Lanka. After removing the surface litter, soil samples were taken from 0-15 cm depth by using an auger and mixed thoroughly to make a composite sample. Physico-chemical characteristics of the soil were determined by standard methods. The soil was pre-incubated for a week at $60 \%$ water holding capacity prior to the treatments. Characteristically the soil was loamy sand with $6.3 \mathrm{pH}, 0.85 \%$ organic C, $0.13 \%$ total $\mathrm{N}, 125 \mathrm{mg} / \mathrm{kg}$ borax P, $45 \mathrm{mg} / \mathrm{kg}$ exchangeable $\mathrm{K}$ and $12.1 \mathrm{cmol} / \mathrm{kg}$ CEC. Organic carbon and total nitrogen contents in vermicompost were 39 and $1.02 \%$, respectively and the corresponding figures for the coir dust were 45 and $0.39 \%$.

\section{Treatments}

Sub samples of $100 \mathrm{~g}$ of homogeneously mixed air dry soil were placed in glass bottles. Bottles were watered to adjust the moisture content to $50 \%$ of the field capacity (dry basis) and maintained by daily monitoring and adding water when necessary. Bottles were then kept in dark for two weeks prior to addition of plant materials. After two-week preincubation period, the glass bottles were opened and different percentages of vermicompost and coir dust were used in making four different mixtures and mixed thoroughly with the soil. The treatments were $100 \%$ vermicompost $\left(\mathrm{T}_{1}\right), 75 \%$ vermicompost $+25 \%$ coir dust $\left(\mathrm{T}_{2}\right), 50 \%$ vermicompost $+50 \%$ coir dust $\left(\mathrm{T}_{3}\right), 25 \%$ vermicompost $+75 \%$ coir dust $\left(\mathrm{T}_{4}\right)$ and control $\left(T_{5}\right)$. This rate of application was 5 tons per hectare on the assumption that $l$ ha soil with $15 \mathrm{~cm}$ depth contains $2.13 \times 10^{9} \mathrm{~kg}$ soil (soil bulk density 1.42 $\mathrm{g} \mathrm{cm}^{-3}$ ). The treated soil samples along with the controls (free from treatments) were incubated in the dark at room temperature $\left(25 \pm 1^{\circ} \mathrm{C}\right)$. Constant moisture content of the soil was maintained throughout the incubation period. 


\section{Carbon mineralization}

Soil samples were placed in gas-tight glass containers along with a vial containing $10 \mathrm{ml}$ of $1 \mathrm{M} \mathrm{NaOH}$ to trap $\mathrm{CO}_{2}$ and a vial of water to maintain humidity. Soil was incubated at room temperature $\left(25^{\circ} \mathrm{C}\right)$ in the dark and $\mathrm{NaOH}$ traps were replaced at 2, 5, 7, 14, 21, 28, 35, 42, 49, 56, 63 and 70 days after the treatment. Unreacted alkali in the $\mathrm{NaOH}$ traps was titrated with $0.5 \mathrm{M}$ HC1 to determine $\mathrm{CO}_{2}-\mathrm{C}$ released from the soil (Anderson, 1982).

\section{Nitrogen mineralization}

Nitrogen mineralization was determined in terms of inorganic $\mathrm{N}\left(\mathrm{NH}_{4}{ }^{+}-\mathrm{N}\right.$ and $\mathrm{NO}^{-3}-\mathrm{N}$ ) concentration of soil extracted at 2, 5, 7, 14, 21, 28, 35, 42, 49, 56, 63 and 70 days after incubation. Samples containing $10 \mathrm{~g}$ soil were extracted using $30 \mathrm{ml}$ of $2 \mathrm{M} \mathrm{KCI}$ and the extracts was used to determine $\mathrm{NH}_{4}{ }^{+}-\mathrm{N}$ and $\mathrm{NO}_{3}{ }^{-} \mathrm{N}$. The $\mathrm{NH}_{4}{ }^{+}-\mathrm{N}$ content was determined utilizing the Berthelot reaction (Searle, 1984) and the $\mathrm{NO}_{3}{ }^{-}-\mathrm{N}$ by sodium salicylate yellow colour method (Bremner, 1960).

\section{Results and Discussion}

No significant $(\mathrm{p} \leq 0.05)$ variation was observed among the treatments at day 3 of the incubation. However, treatments $\mathrm{T}_{1}, \mathrm{~T}_{2}$ and $\mathrm{T}_{3}$ were significantly $(\mathrm{p} \leq$ 0.05 ) different from the control at day 7 and treatments $T_{2}$ and $T_{3}$ were significantly $(\mathrm{p} \leq 0.05)$ different from day 14 . Since then, significant $(\mathrm{p} \leq 0.05)$ differences were no longer observed for any treatment until the end of the incubation (Fig. 1).

After 3 days of incubation, the average $C$ mineralized of the soil were 46, 59, 64 and $56 \mathrm{mg} / \mathrm{kg}$ for the treatments $\mathrm{T}_{1}, \mathrm{~T}_{2}, \mathrm{~T}_{3}$ and $\mathrm{T}_{4}$, respectively, and at the end of the 70-day incubation, C mineralization had decreased to 26, 25, 15 and 7 $\mathrm{mg} / \mathrm{kg}$ for the respective treatments. In contrast, $\mathrm{T}_{2}$ (75\% vermicompost $+25 \%$ coir dust) showed higher carbon mineralization than other treatments throughout the incubation period. Furthermore, control exhibited the lowest carbon mineralization. In addition, all treatments inhibited the carbon mineralization as incubation progressed.

The effect of different mixtures of vermicompost and coir dust on nitrogen mineralization in soil is shown in Fig. 2 and 3. Variation in soil $\mathrm{NH}_{4}{ }^{+}-\mathrm{N}$ during the first 3 days of incubation was significantly different $(\mathrm{p} \geq 0.05)$ in treatments $\mathrm{T}_{1}, \mathrm{~T}_{2}$ and $\mathrm{T}_{3}$ (Fig. 2). No distinct relationships were found after day 3 of incubation and $\mathrm{NH}_{4}{ }^{+}-\mathrm{N}$ contents were highly varied throughout the incubation. However, control $\left(T_{5}\right)$ was found to be significantly different $(p \geq 0.05)$ from other treatments towards the end of the incubation. Furthermore, it was observed that $\mathrm{NH}_{4}{ }^{+}-\mathrm{N}$ contents were increased at the initial stage of the incubation followed by gradual 
reductions. The initial increment might be due to organic $\mathrm{N}$ ammonification or from depression of ammonium oxidation activity. Treatment $\mathrm{T}_{2}$ was found to exhibit the highest $\mathrm{NH}_{4}{ }^{+}-\mathrm{N}$ contents followed by treatment $\mathrm{T}_{1}$ and $\mathrm{T}_{3}$.
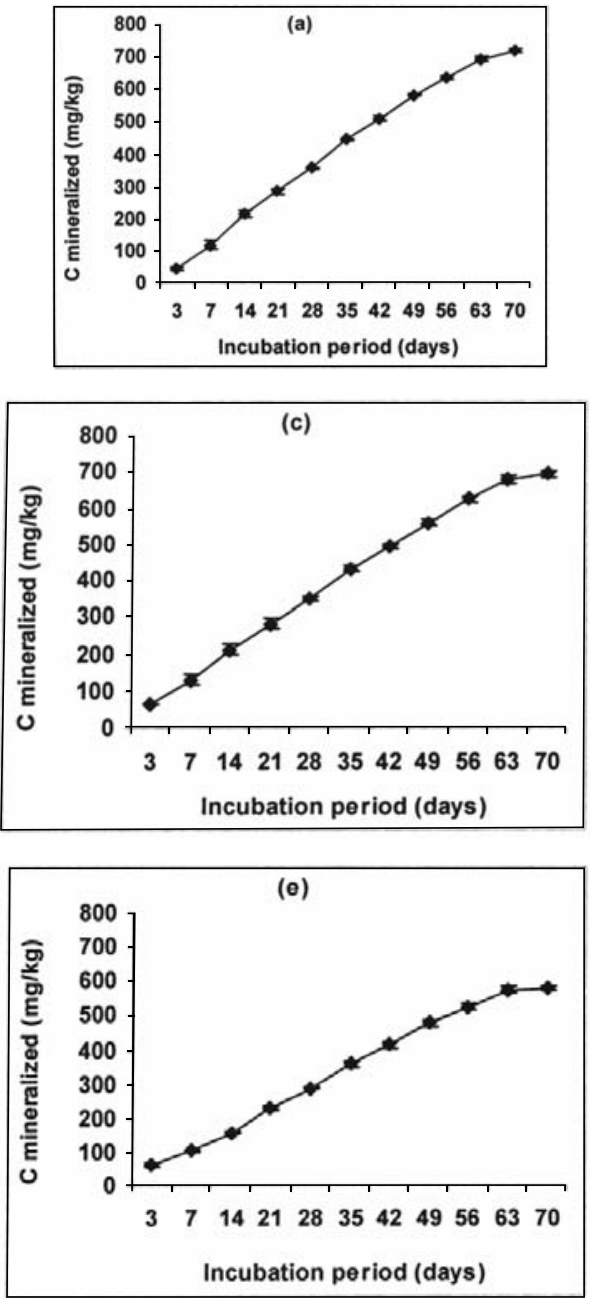
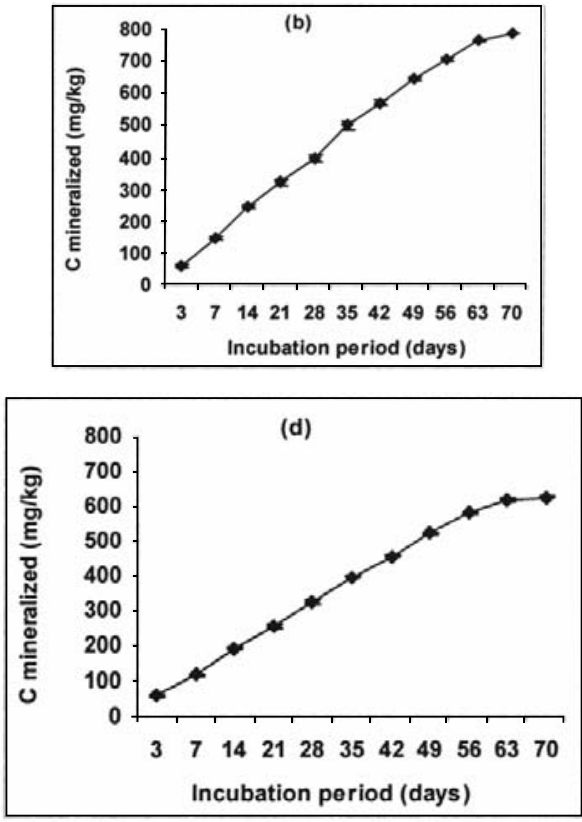

Fig. 1. Cumulative $\mathrm{C}$ mineralization of the soil amended with different combinations of vermicompost and coir dust. (a), (b), (c), (d) and (e) represent treatment $\mathrm{T}_{1}$, $\mathrm{T}_{2}, \mathrm{~T}_{3}, \mathrm{~T}_{4}$ and $\mathrm{T}_{5}$, respectively. Values are the means of 4 replications.

Fig. 3 shows the soil $\mathrm{NO}_{3}-\mathrm{N}$ variation during the incubation period. According to the results, $\mathrm{NO}_{3}-\mathrm{N}$ contents were highly varied at the initial stages of incubation with no distinct relationships among the treatments. However, as incubation progressed, the $\mathrm{NO}_{3}-\mathrm{N}$ contents were increased for all the treatments. It was also observed that the $\mathrm{NO}_{3}-\mathrm{N}$ increment in treatment $\mathrm{T}_{1}$ was significantly $(p \geq 0.05$ ) higher than those of other treatments. This might be due to enhanced mineralization of organic $\mathrm{N}$. At the end of the incubation (last 2 weeks), $\mathrm{NO}_{3}-\mathrm{N}$ contents in all the treatments were significantly different $(p \geq 0.05)$ from the 
control. However, the values for treatments $T_{2}, T_{2}$ and $T_{3}$ were not significantly different ( $\mathrm{p} \geq 0.05$ ) from each other.
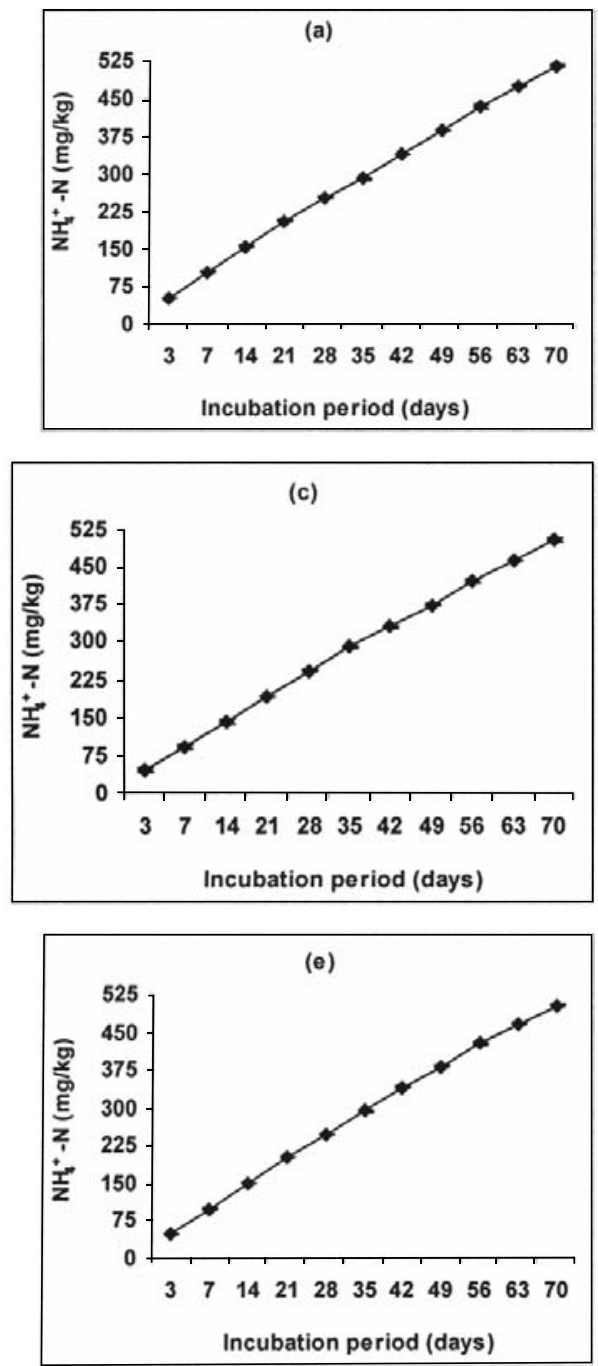
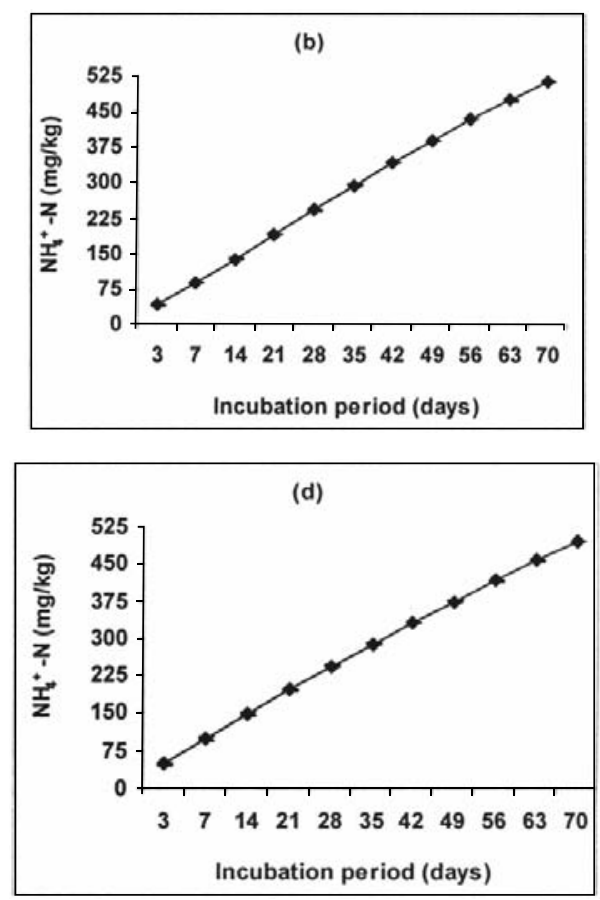

Fig. 2. Release of $\mathrm{NH}_{4}{ }^{+} \mathrm{N}$ from the soils amended with different combinations of vermicompost and coir dust. (a), (b), (c), (d) and (e) represent treatment $T_{1}, T_{2}, T_{3}$, $\mathrm{T}_{4}$ and $\mathrm{T}_{5}$, respectively. Values are the means of 4 replications. 

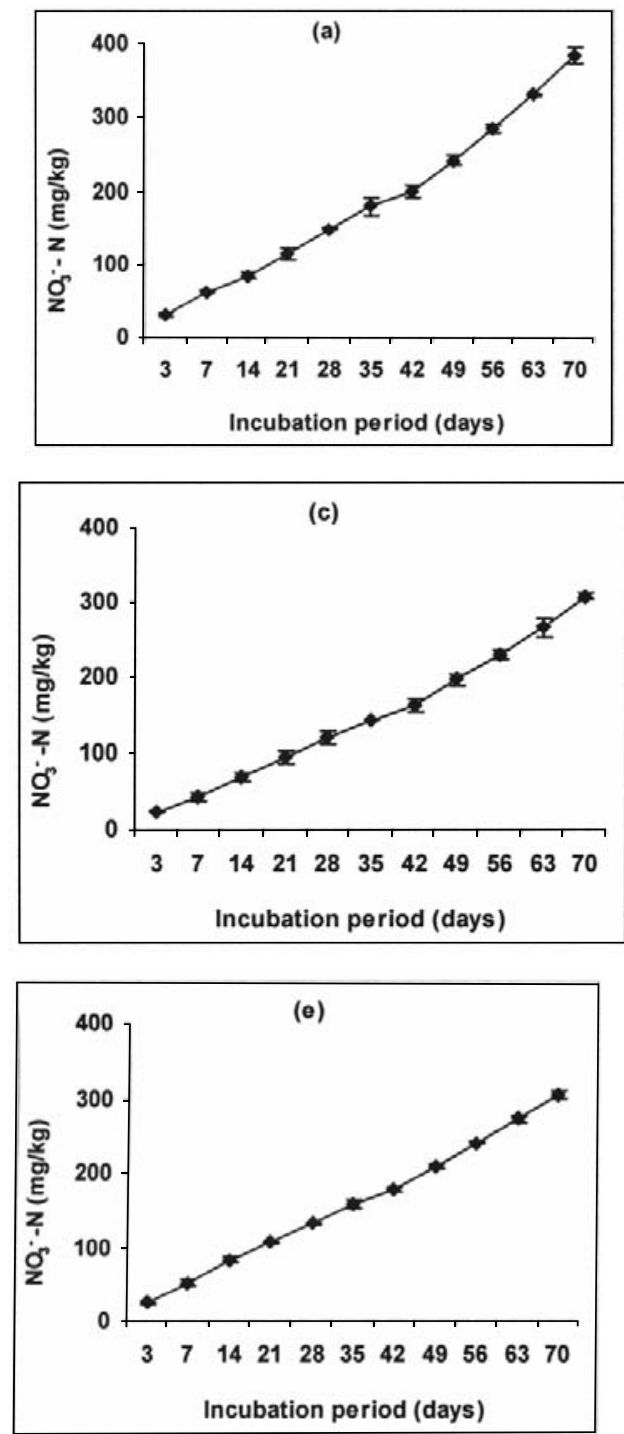
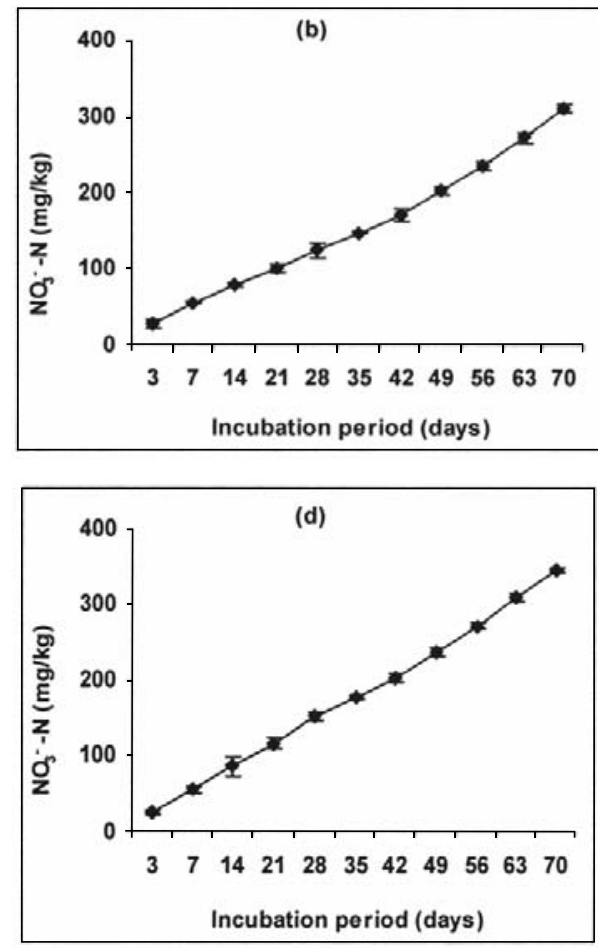

Fig. 3. Release of $\mathrm{NO}_{3}{ }^{-}-\mathrm{N}$ from the soils amended with different combina-tions of vermicompost and coir dust. (a), (b), (c), (d) and (e) represent treatment $\mathrm{T}_{1}$, $T_{2}, T_{3}, T_{4}$ and $T_{5}$. respectively. Values are the means of 4 replications.

However, previous studies have shown that $100 \%$ vermicompost can not be used as it is, due to poor porosity, aeration and high soluble salt concentrations (Atiyeh et al., 2000). On the other hand, 75\% coir dust also can not be used due to its low nutrient content. Such result is applicable to the present investigation that treatments $T_{1}$ and $T_{4}$ did not show positive results in terms of microbial respiration and $\mathrm{N}$ mineralization. 


\section{Conclusion}

The combination of $75 \%$ vermicompost and $25 \%$ coir dust showed better performance in terms of carbon mineralization and thus more effectively enhanced the microbial activity compared to other treatments. The $\mathrm{NH}_{4}{ }^{+}-\mathrm{N}$ contents in all the treatments were found to be increased at the initial stage of the incubation followed by gradual reductions. Treatment $\mathrm{T}_{2}$ showed the highest $\mathrm{NH}_{4}{ }^{+}-\mathrm{N}$ contents followed by treatment $\mathrm{T}_{1}$ and $\mathrm{T}_{3}$. The $\mathrm{NO}_{3}-\mathrm{N}$ contents were highly varied at the initial stages of the incubation with no distinct relationships among the treatments. However, as incubation progressed, $\mathrm{NO}_{3}-\mathrm{N}$ contents were increased for all the treatments with the highest increment for $T_{1}$ followed by $T_{2}$ and $\mathrm{T}_{3}$.

\section{References}

Anderson, J. P. E. 1982. Soil respiration. In. A.L.Page (ed.) Methods of Soil Analysis. Part 2. Chemical and Microbiological Methods. Edition. Amer. Soc. Agron. pp. 837871.

Atiyeh, R.M., C. A. Edwards, Sublers and J. D. Metzger. 2000. Pig manure vermicompost as a component of a horticultural bedding plane medium: Effects on physicochemical properties and plant growth, Bioresource Technology 78:11-20.

Bremner, J. M., and C. S. Mulvaney. 1982. Total nitrogen. In. A.L.Page (ed.) Methods of Soil Analysis. Part 2. Chemical and Microbiological Methods. 2nd Edition. Amer. Soc. Agron. pp. 1149-1178.

Cresswell, D. C. 2006 Coir dust-a viable alternative to peat, Biological and Chemical Research Institute, Australia, pp. 5-11.

Mapa, R. B., S. Somssiri and S. Nagarajah. 1999. Soils of the wet zone of Sri Lanka. Soil Sci. Soc. SL. pp. 23-92.

Sajnanath, K. and P. K. Sushama. 2004. Recycling of bio-wastes through vermicomposting, Agrobios, Updesh Purohit for Agrobios, Jodhpur. pp. 33-35.

Searle, P.L. 1984. The Berthelot or indophenol reaction and its use in the analytical chemistry of nitrogen: a review, Analyst. 109: 549-568.

Sharma, A. K. 2003. Biofertilizers for Sustainable Agriculture, Updesh Purohit for Agrobios, India. pp. 41-46.

Thampan, P.K. 1981. Hand Book of Coconut Palm, Mohan Primlani, Oxford and TBH Publishing Co., New Delhi. pp. 272-274. 